ARTICLE

\title{
Site-selective electrooxidation of methylarenes to aromatic acetals
}

Peng Xiong ${ }^{1}$, Huai-Bo Zhao ${ }^{1}$, Xue-Ting Fan ${ }^{1}$, Liang-Hua Jie ${ }^{1}$, Hao Long ${ }^{1}$, Pin Xu' ${ }^{1}$, Zhan-Jiang Liu' ${ }^{1}$ Zheng-Jian Wu', Jun Cheng (1D ${ }^{1 \otimes} \&$ Hai-Chao Xu (1) ${ }^{1,2 \otimes}$

Aldehyde is one of most synthetically versatile functional groups and can participate in numerous chemical transformations. While a variety of simple aromatic aldehydes are commercially available, those with a more complex substitution pattern are often difficult to obtain. Benzylic oxygenation of methylarenes is a highly attractive method for aldehyde synthesis as the starting materials are easy to obtain and handle. However, regioselective oxidation of functionalized methylarenes, especially those that contain heterocyclic moieties, to aromatic aldehydes remains a significant challenge. Here we show an efficient electrochemical method that achieves site-selective electrooxidation of methyl benzoheterocycles to aromatic acetals without using chemical oxidants or transition-metal catalysts. The acetals can be converted to the corresponding aldehydes through hydrolysis in one-pot or in a separate step. The synthetic utility of our method is highlighted by its application to the efficient preparation of the antihypertensive drug telmisartan.

\footnotetext{
${ }^{1}$ State Key Laboratory of Physical Chemistry of Solid Surfaces, Innovative Collaboration Center of Chemistry for Energy Materials, and College of Chemistry and Chemical Engineering, Xiamen University, 361005 Xiamen, PR China. ${ }^{2}$ Key Laboratory of Chemical Biology of Fujian Province, Xiamen University, 361005 Xiamen, PR China. ${ }^{凶}$ email: chengjun@xmu.edu.cn; haichao.xu@xmu.edu.cn
} 
Denzylic oxygenation of alkylarenes provides crucial access to many industrial chemicals, such as terephthalic acid, phenol, and acetone, on a multimillion-ton scale ${ }^{1}$. Aldehyde is one of the most versatile synthetic handles and can be converted to numerous functionalities. As a result, aromatic aldehydes have been widely used in the manufacture of fine chemicals, nutraceuticals, performance materials, and pharmaceuticals. The oxygenation of methylarenes is a straightforward and attractive strategy for the preparation of aromatic aldehydes, especially considering that the starting materials are widely available and easy to handle. However, partial oxidation of methylarenes to aldehydes remains a largely unsolved challenge due to the strong propensity of product overoxidation under aerobic conditions (Fig. 1a) $)^{2,3}$, and unsatisfactory chemo- and regioselectivity with substrates bearing multiple oxidizable $\mathrm{C}-\mathrm{H}$ bonds and/or functionalities ${ }^{4}$. Despite these difficulties, oxygenation of simple methylarenes to aldehydes has been achieved using stoichiometric chemical oxidants such as $o$-iodoxybenzoic acid $(\mathrm{IBX})^{5}$, ceric ammonium nitrate $(\mathrm{CAN})^{6}$, pyridinium chlorochromate ${ }^{7}$ or polyoxometalate $\mathrm{H}_{5} \mathrm{PV}_{2} \mathrm{Mo}_{10} \mathrm{O}_{40}{ }^{8}$. Transition metal-catalyzed aerobic oxidation using hexafluoro-2-propanol as solvent ${ }^{9}$ or by adding polymethylhydrosiloxane as reagents to avoid overoxidation ${ }^{10}$ have also been reported (Fig. 1a). As an alternative to chemical oxidation, electrooxidation eliminates the use of stoichiometric chemical oxidants and is attracting increasing interests ${ }^{11-26}$. Notably, electrooxidation of electron-rich toluene derivatives to substituted benzaldehydes has been applied in the industrial production of $p$ anisaldehyde and 3,4,5-trimethoxybenzaldehyde ${ }^{27-29}$. Despite these accomplishments, the conversion of structurally complex methylarenes, including medicinally relevant benzoheterocycles in particular, has remained synthetically elusive because of selectivity issues and catalyst inhibition by the coordinating heteroatoms $\mathrm{s}^{30}$. a

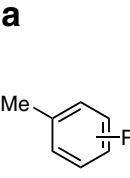

Simple toluene derivatives
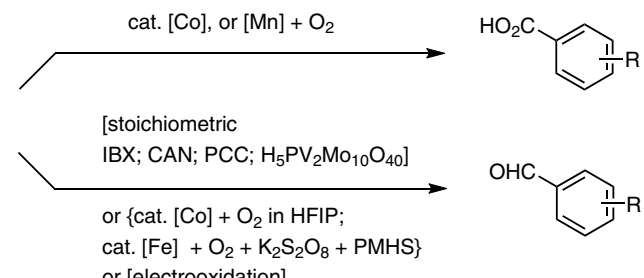

or [electrooxidation]

b
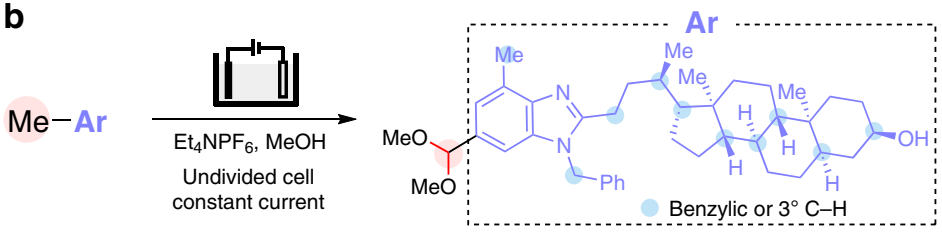

$52 \%$ yield (single product)

Fig. 1 Methylarene oxidation. a Examples of reported oxidation of relatively simple toluene derivatives to benzoic acids or benzaldehydes. $\mathbf{b}$ The present study focuses on site-selective electrooxidation of methyl benzoheterocycles to aromatic aldehydes.

Table 1 Optimization of reaction conditions ${ }^{a}$.

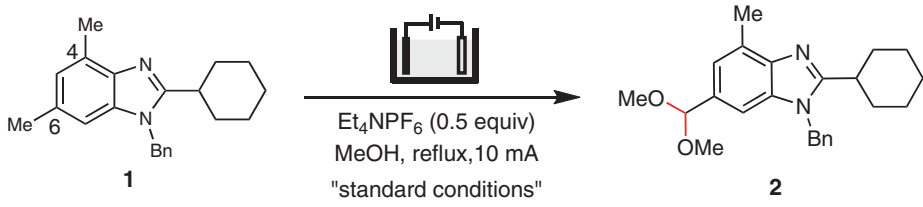

\begin{tabular}{|c|c|c|}
\hline Entry & Deviation from standard conditions & Yield (\%) \\
\hline 1 & None & $72^{c}$ \\
\hline 2 & Reaction at RT & 25 \\
\hline 3 & Reaction at $8 \mathrm{~mA}$ & 61 \\
\hline 4 & Reaction at $12 \mathrm{~mA}$ & 66 \\
\hline 5 & Reaction under air & 50 \\
\hline 6 & $\mathrm{Et}_{4} \mathrm{NPF}_{6}$ (0.2 equiv) & 63 \\
\hline 7 & $\mathrm{Et}_{4} \mathrm{NBF}_{4}$ instead of $\mathrm{Et}_{4} \mathrm{NPF}_{6}$ & 72 \\
\hline 8 & $n-\mathrm{Bu}_{4} \mathrm{NPF}_{6}$ instead of $\mathrm{Et}_{4} \mathrm{NPF}_{6}$ & 64 \\
\hline 9 & $\mathrm{Et}_{4} \mathrm{NOTs}$ instead of $\mathrm{Et}_{4} \mathrm{NPF}_{6}$ & 66 \\
\hline 10 & Pt plate $(1 \mathrm{~cm} \times 1 \mathrm{~cm})$ as anode & $20(69)^{d}$ \\
\hline 11 & $\begin{array}{l}\text { Graphite plate }(1 \mathrm{~cm} \times 1 \mathrm{~cm}) \\
\text { as anode }\end{array}$ & 56 \\
\hline
\end{tabular}




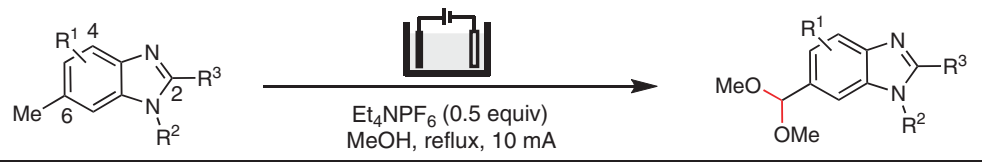<smiles>COC(OC)c1cc2c(nc(C3CCCCC3)n2Cc2ccccc2)c([N+](=O)[O-])c1-c1ccccc1</smiles>

$3,67 \%$<smiles>COC(OC)c1cc([N+](=O)[O-])c2nc(C3CCCCC3)n(CCBr)c2c1</smiles><smiles>COC(OC)c1cc([N+](=O)[O-])c2nc(-c3ccccc3C)n(C)c2c1</smiles>

$11,54 \%$<smiles>COC(=O)CCc1nc2c([N+](=O)[O-])cc(C(OC)OC)cc2n1Cc1ccccc1</smiles>

$15,57 \%$<smiles>COC(OC)c1cc([N+](=O)[O-])c2nc(CCC(C)=O)n(Cc3ccccc3)c2c1</smiles>

$19,61 \%$<smiles>COC(OC)c1cc(C)c2nnc([C@@H]3CCCN3C(=O)C(NCc3ccccc3)C(C)C)n2c1</smiles>

23, $65 \%$

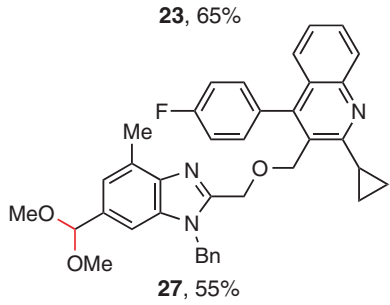<smiles></smiles><smiles>COC(OC)c1cc2c(nc(C3CCCCC3)n2Cc2ccccc2)c([N+](=O)[O-])c1Br</smiles>

4, $55 \%$<smiles>C#CCn1c(C2CCCCC2)nc2c([N+](=O)[O-])cc(C(OC)OC)cc21</smiles><smiles>COC(OC)c1cc([N+](=O)[O-])c2nc(-c3cccs3)n(Cc3ccccc3)c2c1</smiles>

$12,50 \%$<smiles>COC(OC)c1cc([N+](=O)[O-])c2nc(COC(=O)C(=O)C(C)(C)C)n(Cc3ccccc3)c2c1</smiles>

$16,60 \%$<smiles>COC(OC)c1cc([N+](=O)[O-])c2nc(COCc3cccc(C=O)c3)n(Cc3ccccc3)c2c1</smiles>

20, $50 \%$<smiles>COC(OC)c1cc([N+](=O)[O-])c2nc([C@H]3COC(C)(C)O3)n(Cc3ccccc3)c2c1</smiles>

$24,63 \%$<smiles>COC(OC)c1cc2c(nc(C3CCCCC3)n2Cc2ccccc2)c([N+](=O)[O-])c1C#N</smiles>

$5,70 \%$<smiles>C=CCn1c(CCC)nc2c(C)cc(C(OC)OC)cc21</smiles>

$9,60 \%$<smiles>COC(OC)c1cc([N+](=O)[O-])c2nc(-c3nccs3)n(C)c2c1</smiles>

$13,74 \%$<smiles>COC(OC)c1cc([N+](=O)[O-])c2nc(C(C)O)n(Cc3ccccc3)c2c1</smiles><smiles>COC(OC)c1cc([N+](=O)[O-])c2nc([C@@H](C)NC(=O)c3ccccc3)n(Cc3ccccc3)c2c1</smiles>

21, $62 \%$<smiles>COC(OC)c1cc(C)c2nc(C3CCCCC3)n(C)c2c1</smiles><smiles>COC(OC)c1cc([N+](=O)[O-])c2nc(C3CCCCC3)n(C(=O)O)c2c1</smiles>

10, $72 \%(C 6: C 4=10: 1)$<smiles>COC(OC)c1cc([N+](=O)[O-])c2nc(C(C)(C)C)n(C)c2c1</smiles>

$14,56 \%$<smiles>COC(OC)c1cc([N+](=O)[O-])c2nc(CO)n(Cc3ccccc3)c2c1</smiles>

$18,61 \%$<smiles>COC(OC)c1cc([N+](=O)[O-])c2nc(C3CN(C(=O)OC(C)(C)C)CCO3)n(Cc3ccccc3)c2c1</smiles>

22, $63 \%$

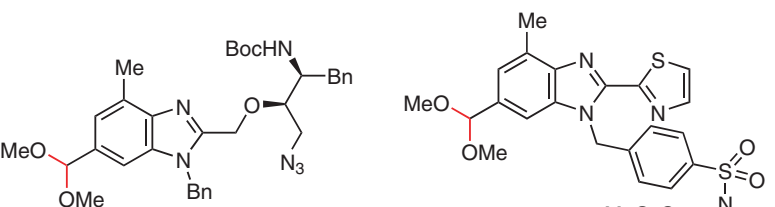
$26,60 \% \mathrm{MeO}_{2} \mathrm{C}{ }^{\mathrm{N}}$ $25,56 \%$

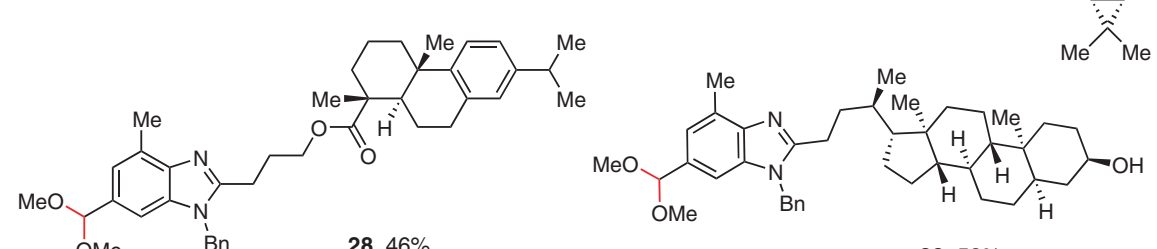

28, $46 \%$<smiles>COC(OC)c1cc2nc(-c3nccs3)n(C)c2cc1C</smiles>

31, $66 \%$<smiles>COc1cc2nc(-c3ccccc3)n(C)c2cc1C(OC)OC</smiles>

32, $67 \%(C 6: C 5=10: 1)$
$29,52 \%$<smiles>COC(OC)c1cc2c(cc1C)nc(C1CCCCC1)n2Cc1ccccc1</smiles>

33, $69 \%(C 6: C 5=3: 1)$

Fig. 2 Scope of site-selective electrooxidation of benzimidazoles. Reaction conditions: heterocycle $(0.2 \mathrm{mmol}), \mathrm{MeOH}(0.022 \mathrm{M})$, reflux, $2.2-4.5 \mathrm{~h}$. All yields are isolated yields. Regioisomers were not observed unless otherwise mentioned. 
We have been interested in electrochemical synthesis of heterocycles $23,31,32$ and recently reported intramolecular dehydrogenative cyclization reactions for the preparation of several types of benzoheterocycles ${ }^{33-37}$. Alternatively, we envision the synthesis of functionalized benzoheterocycles by modification of alkyl side chains of existing benzoheterocyclic scaffolds. Herein we report a generally applicable electrochemical strategy capable of oxidizing various methyl benzoheterocycles to aromatic acetals in a site-selective manner (Fig. 1b). These side chain oxidation reactions allow access to various functionalized benzoheterocycles difficult to obtain directly through cyclization processes.

\section{Results}

Reaction optimization. We began our study by first optimizing the electrooxidation of benzimidazole 1 bearing Me groups at positions 4 and 6 (Table 1). The best results were achieved in an undivided cell with refluxing methanol as solvent, $\mathrm{Et}_{4} \mathrm{NPF}_{6}$ ( 0.5 equiv) as electrolyte, a Pt plate cathode, and a reticulated vitreous carbon anode. Under these conditions, compound 1 reacted site-selectively at C6-Me group to give dimethyl acetal
2 in $72 \%$ yield (entry 1 ) without overoxidation to orthoester or unwanted oxidation of other potentially labile substituents such as $\mathrm{C} 4-\mathrm{Me}, \mathrm{N}-\mathrm{Bn}$, or $3^{\circ} \mathrm{C}-\mathrm{H}$ on the cyclohexyl moiety. Lowering the reaction temperature to RT dramatically decreased the yield of $\mathbf{2}$ to $25 \%$ (entry 2). Furthermore, moderate reduction in reaction efficiency was observed when the electrolysis of $\mathbf{1}$ was performed at a different current (entries 3 and 4), under air (entry 5), with a decreased amount of $\mathrm{Et}_{4} \mathrm{NPF}_{6}$ (entry 6), or with another electrolyte such as $n$ - $\mathrm{Bu}_{4} \mathrm{NPF}_{6}$ (entry 8) or $\mathrm{Et}_{4} \mathrm{NOT}_{\text {s }}$ (entry 9). $\mathrm{Et}_{4} \mathrm{NBF}_{4}$ (entry 7) was, however, equally effective as a supporting electrolyte. Product formation was also diminished with the use of a $\mathrm{Pt}$ (entry 10) or graphite anode (entry 11).

Evaluation of substrate scope. With the optimized reaction conditions defined, we set out to explore the scope of the electrooxidation of methylarenes. Notably, the site-selectivity was not significantly affected by introducing a phenyl (3), bromo (4), or cyano group (5) at C5, or by varying the substituent on N1 (6-9) or C2 (11-29) of the C4,C6-dimethylated benzimidazole substrate (Fig. 2). However, the installation of a carbamoyl group on N1

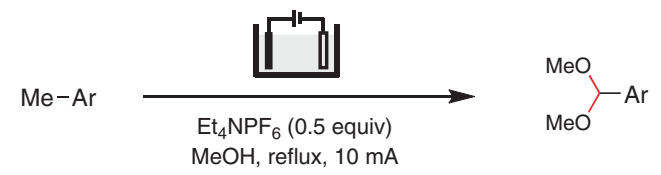<smiles>COC(O[Na])c1cc([N+](=O)[O-])c2nc(P)oc2c1</smiles>

$34,60 \%$<smiles>O=[N+]([O-])c1cc2nc(-c3ccccc3)sc2cc1P</smiles>

38, $\mathrm{R}=\mathrm{CH}(\mathrm{OMe})_{2}, 75 \%$ $39, \mathrm{R}=\mathrm{CHO}, 57 \%^{\mathrm{a}}$<smiles>COc1cc2nc(-c3ccccc3)sc2c([N+](=O)[O-])c1C</smiles>

$42,53 \%(R=H)$ $+43,13 \%(R=O M e)$<smiles>COC(O[C@H](O)c1cc2oc(=O)n(C)c2cc1C)c1ccccc1</smiles>
$47,86 \%$<smiles>Cc1cc(C=O)ccc1O</smiles>

$52,67 \%^{\mathrm{a}}$<smiles>COC(OC)c1cc2oc(-c3ccccc3)nc2c([N+](=O)[O-])c1Br</smiles>

$35,56 \%$<smiles>COC(OC)c1cc2oc(-c3ccccc3)nc2cc1O</smiles>

$36,67 \%$<smiles>COC(OC)c1cc2oc([PH2+])nc2cc1COC(C)c1cc2nc(-c3ccccc3)oc2cc1C</smiles>
[separated]

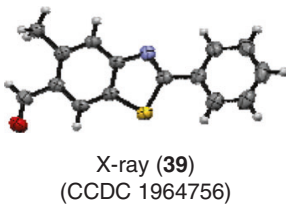<smiles>COC(OC)c1cc([N+](=O)[O-])c2nc(-c3ccccc3)sc2c1</smiles><smiles>COC(O[C@H](O)c1cc2sc(-c3ccccc3)nc2cc1C(C)C)c1ccccc1</smiles>
[separated]<smiles>C=Nc1ccc(C(OC)OC)c2nc(-c3cc([N+](=O)[O-])cc([N+](=O)[O-])c3)sc12</smiles>
44, $57 \%+44 ', 10 \%$ [separated]<smiles>COC(OC)c1cc([N+](=O)[O-])c2c(c1)n(C)c(=O)n2C</smiles>

$45,84 \%$<smiles>COC(=O)c1c(-c2ccccc2)cc2c(c1CCCOC(=O)c1ccccc1)n(Cc1ccccc1)c(=O)n2C</smiles>

46, $\mathrm{R}=\mathrm{OMe}, 67 \%\left(9.9 \mathrm{~F} \mathrm{~mol}^{-1}\right)$ $46^{\prime}, \mathrm{R}=\mathrm{H}, 74 \%\left(4.1 \mathrm{~F} \mathrm{~mol}^{-1}\right)$<smiles>COC(O[Na])c1cc(-c2ccccc2)c2c(oc(=O)n2P)c1[N+](=O)[O-]</smiles>

$48,75 \%$

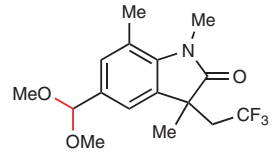

$49,84 \%$<smiles>[C]OC(OC)c1cc([N+](=O)[O-])c2c(c1)C(C(C)=O)(C(C)=O)CC(=O)N2C</smiles>

50, $96 \%$<smiles>COC(OC)c1cc2nc(-c3ccccc3)c(=O)n([N+](=O)[O-])c2cc1C</smiles>

$51,55 \%$<smiles>CC(C)(C)CCCCOc1cc([N+](=O)[O-])ccc1C=O</smiles><smiles>COc1ccc(C)c(N)c1</smiles>

55 (failed substrate)

Fig. 3 Electrooxidation of various methyl benzoheterocycles. Reaction conditions: methylarene $(0.2 \mathrm{mmol}), \mathrm{MeOH}(0.022 \mathrm{M})$, reflux, $2.2-5.3 \mathrm{~h}$. All yields are isolated yields. Regioisomers were not observed unless otherwise mentioned. aElectrolysis was followed by hydrolysis with aqueous $\mathrm{HCl}(2 \mathrm{~N}$ ). 
resulted in a slight decrease of regioselectivity (10). The method showed broad compatibility with common functional groups or moieties such as alkyl bromide (7), alkyne (8), alkene (9), ester $(15,16)$, alcohol $(17,18)$, ketone (19), aldehyde (20), Bocprotected amine (21-23), ketal (24), azido (25), and aromatic heterocycles $(12,13,26$, and 27). Molecular fragments derived from natural products dehydroabietic acid (28) and lithocholic acid (29) were equally well tolerated. On the other hand, siteselective oxidation of the C6-Me group in C5,C6-dimethylated benzimidazoles bearing an aryl substituent at $\mathrm{C} 2(\mathbf{3 0}-\mathbf{3 2})$ could also be achieved. The replacement of the aryl group with a cyclohexyl, however, resulted in a moderate site-selectivity (33). This reduction in site-selectivity for the 2-cyclohexyl substrate was probably caused by the increased reactivity of the corresponding radical cation compared with the 2-aryl counterparts.

Benzoxazoles (34-37) and benzothiazoles (38, 40-42) with multiple open benzylic positions were all found to undergo siteselective oxidation at the C6-Me group (Fig. 3). The siteselectivity was maintained even for substrates bearing an ethyl (37) or isopropyl group (41) at C5 that contained secondary or tertiary benzylic $\mathrm{C}-\mathrm{H}$ bonds. Notably, the oxidation of 5,6,7trimethyl benzothiazole proceeded site-selectively as intended despite the high steric hindrance of its C6-Me substituent. However, the resultant product mixture comprised monomethoxylated $\mathbf{4 2}$ as the main product with a minor amount of acetal 43, because the steric environment was detrimental to the second $\mathrm{C}-\mathrm{H}$ cleavage ${ }^{38}$. Meanwhile, oxidation of a C4,C7dimethylated benzothiazole with a methylated phenyl group on $\mathrm{C} 2$ occurred preferentially on the C4-Me (44). The electrooxidation method was successfully extended to many other benzoheterocycles, including 2-benzimidazolidinone $(45,46), 2$ benzoxazolone $(47,48)$, 2-oxindole (49), 3,4-dihydro-1H-quinolin-2-one (50), and quinoxalinone (51). Once again, probably due to the steric hinderance, monomethoxylated product $\mathbf{4 6}^{\prime}$ could be obtained selectively with good yield when the electrolysis was stopped at $4.1 \mathrm{~F} \mathrm{~mol}^{-1}$. The electrochemical method was not limited to benzoheterocycles as demonstrated by the site-selective oxidation of methylated alkoxybenzenes (52-54). The relatively electron-deficient 3,4-dimethylphenylboronic acid (55), however, decomposed into intractable material and did not afforded any aldehyde product. The above results clearly suggested that the site-selectivity for the electrochemical benzylic oxidation reaction are not controlled by steric effects or bond dissociate energies (BDEs) of the $\mathrm{C}-\mathrm{H}$ bonds.

The Me oxidation reaction could be coupled with amidine cyclization that we previously described to construct functionalized benzimidazoles (56-65) and imidazopyridines (66-70) (Fig. 4) ${ }^{33}$. The reaction of an amidine containing a 3,4disubstituted phenyl ring afforded two products 62 and $\mathbf{6 2}^{\prime}$ because of unselective cyclization. The benzylic oxidation was, however, selective for both regioisomers. Compound 71 did not undergo further Me oxidation because its oxidation potential exceeded the decomposition potential of $\mathrm{MeOH}$ solvent. The tandem cyclization/Me oxidation process provided access to benzimidazoles with substitution patterns difficult for the existing methods 33,39 .

Synthesis of telmisartan. The synthetic utility of our electrooxidation reaction was demonstrated through the construction of
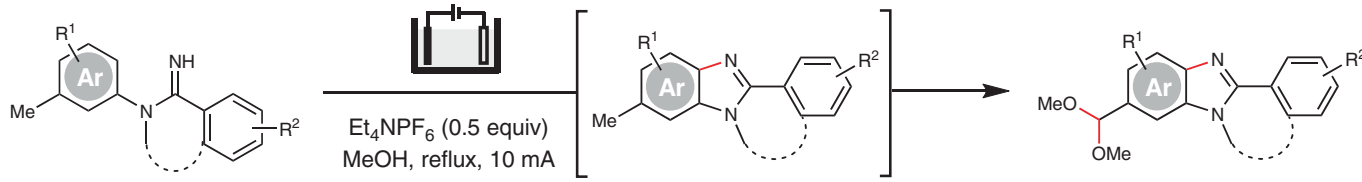

Cyclization

Me oxidation

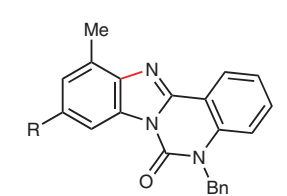

56, $\mathrm{R}=\mathrm{CH}(\mathrm{OMe})_{2}, 71 \%$ (8.3 grams) 57, $\mathrm{R}=\mathrm{CHO}, 77 \%{ }^{\mathrm{a}}$<smiles>COC(OC)c1cc2c(nc3c4ccc(C)cc4n(C)c(=O)n23)c([N+](=O)[O-])c1C</smiles>

$61,73 \%$<smiles>[R]c1ccccc1-c1nc2c(C)cc(C(OC)OC)cc2n1C</smiles>

64, $R=M e, 53 \%$ 65, $\mathrm{R}=\mathrm{Br}, 51 \%$<smiles>COc1c(C(OC)OC)cc2c(nc3c4ccccc4n(S(C)(=O)=O)c(=O)n23)c1OC</smiles>

58, $86 \%$<smiles>COC(OC)c1cc2c(cc1C(C)C)nc1c3ccccc3n(C)c(=O)n21</smiles>

$62,51 \%+62 ', 34 \%$<smiles></smiles>

$66,62 \%$<smiles>COc1cc2c(nc3c4ccccc4n(C)c(=O)n23)c(C)c1F</smiles>

$59,84 \%$<smiles>COC(OC)c1c(C(C)C)ccc2c1nc1c3ccccc3n(C)c(=O)n21</smiles><smiles>COC(OC)c1cc2c(nc1P)nc1c3ccccc3n(Cc3ccccc3)c(=O)n21</smiles>

67, $\mathrm{R}=\mathrm{Me}, 80 \%$

68, $\mathrm{R}=\mathrm{OMe}, 86 \%$

$69, \mathrm{R}=\mathrm{F}, 79 \%$

70, $\mathrm{R}=\mathrm{Cl}, 54 \%$

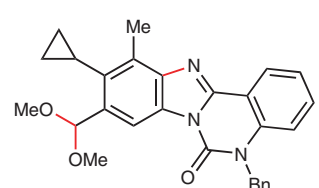

$60,70 \%$<smiles>COC(OC)c1cc([N+](=O)[O-])c2nc(-c3cc(Cl)ccc3Cl)n(C)c2c1</smiles>

63, $54 \%$

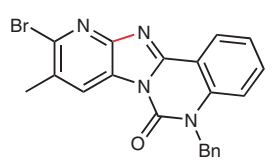

$71,66 \%$

Fig. 4 Electrochemical cyclization/benzylic oxidation of amidines. General reaction conditions: amidine $(0.2 \mathrm{mmol}), \mathrm{MeOH}(0.022 \mathrm{M}), \mathrm{reflux}$, 3.5-12.5 h. All yields are isolated yields. Regioisomers were not observed unless otherwise mentioned. aElectrolysis was followed by one-pot hydrolysis with $\mathrm{HCl}(2 \mathrm{~N})$. 
a

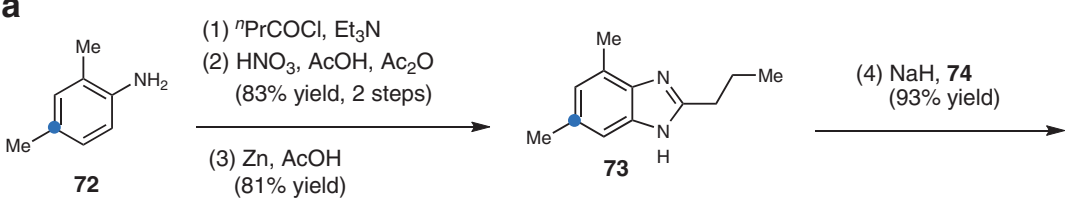<smiles>CC(=O)c1ccc(N)c(C#N)c1</smiles>

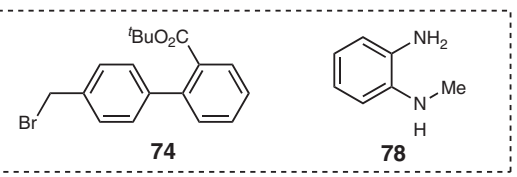<smiles>[M]CCc1nc2c(C)cc(C)cc2n1Cc1ccc(-c2ccccc2C(=O)[O-])cc1</smiles>

(5)

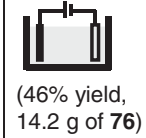

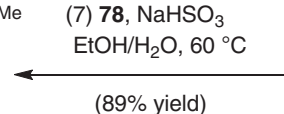

(89\% yield)<smiles>CCCn1c(CCN)nc2c(C)cc(C=O)cc21</smiles><smiles>C[13C](C)[13CH]=[13CH]</smiles><smiles>CNNCc1ccc(-c2ccccc2C(=O)O)cc1</smiles>

Telmisartan

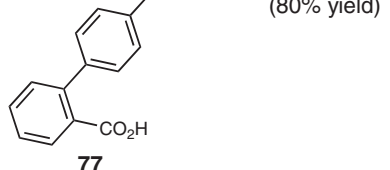

77

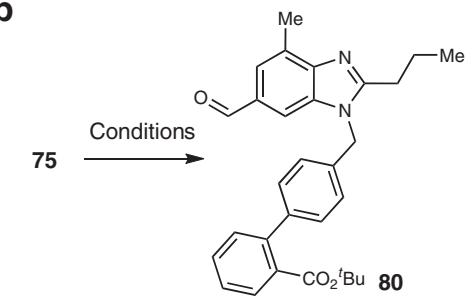

\begin{tabular}{ll}
\multicolumn{3}{c}{ Conditions } \\
\hline 1 & $\mathrm{CAN}(10$ equiv), MeOH, reflux, $22 \mathrm{~h}$ \\
2 & $\mathrm{IBX}\left(10\right.$ equiv), DMSO, $120^{\circ} \mathrm{C}, 24 \mathrm{~h}$ \\
3 & $\mathrm{Co}(\mathrm{OAc})_{2}(2 \mathrm{~mol} \%), \mathrm{NHPI}(10 \mathrm{~mol} \%), \mathrm{O}_{2}, \mathrm{HFIP}, \mathrm{rt}, 24 \mathrm{~h}$ \\
4 & $\mathrm{Cp}_{2} \mathrm{Fe}(10 \mathrm{~mol} \%), \mathrm{FePc}(1 \mathrm{~mol} \%), \mathrm{K}_{2} \mathrm{~S}_{2} \mathrm{O}_{8}(1$ equiv $)$, \\
& PMHS (3 equiv), MeCN/ $\mathrm{H}_{2} \mathrm{O}$, air, $80^{\circ} \mathrm{C}, 20 \mathrm{~h}$
\end{tabular}

$0 \%(50)^{\mathrm{a}}$

$6 \%(38 \%)$

$0 \%(92 \%)$

$<10 \%(42 \%)$

Fig. 5 Synthesis of telmisartan. a Our synthetic route employing site-selective benzylic electrooxidation as a key step. $\mathbf{b}$ Oxidation of $\mathbf{7 5}$ under reported conditions for benzylic oxidation. ${ }^{\mathrm{a}} \mathrm{Me}$ ester was recovered instead of the original ${ }^{\mathrm{t}} \mathrm{Bu}$ ester $\mathbf{7 5}$ because of transesterification. NHPI N-Hydroxyphthalimide, $\mathrm{Fe}(\mathrm{II}) \mathrm{Pc}$ iron(II) phthalocyanine.

the antihypertensive drug telmisartan (Fig. 5a). We first prepared benzimidazole 75 from a commercially available aniline 72 in four steps. Subsequently, site-selective electrooxidation of $\mathbf{7 5}$ afforded dimethyl acetal $\mathbf{7 6}$ in $46 \%$ yield on a decagram scale. In contrast, the oxidation of 75 by a stoichiometric amount of chemical oxidant such as $\mathrm{CAN}^{6}$ or $\mathrm{IBX}^{5}$, in the presence of a Co catalyst under aerobic conditions $^{9}$, or iron catalyzed oxidation ${ }^{10}$ with $\mathrm{K}_{2} \mathrm{~S}_{2} \mathrm{O}_{8}$ afforded $\mathbf{8 0}$ in $<10 \%$ yield despite the success of these methods with toluene derivatives (Fig. 5b). Compound $\mathbf{7 6}$ was then converted to telmisartan by treating with aqueous $\mathrm{HCl}$ to hydrolyze its acetal group to aldehyde and remove its ${ }^{t} \mathrm{Bu}$, followed by condensation with $o$-phenylenediamine 78. Notably, the starting material $\mathbf{7 2}$ employed in this synthetic route are much less expensive than ester $\mathbf{7 9}$ used in a previously published 8-step method ${ }^{40}$.

Mechanistic investigation. The reaction regioselectivity that we observed in this study suggested that the mechanism likely involved single electron transfer oxidation of the benzene nucleus to a radical cation, followed by benzylic $\mathrm{C}-\mathrm{H}$ cleavage ${ }^{28}$. This hypothesis is further supported by the finding that bromination of benzoxazole $\mathbf{8 1}$ with NBS, known to proceed through hydrogen atom transfer, afforded a regioisomeric mixture of $\mathbf{8 2}(50 \%)$ and 83 (17\%) along with dibrominated 84 (10\%) (Fig. 6a). Density functional theory calculations were also performed to provide a plausible rationale for the origin of the observed siteselectivity (Fig. 6b). We first analyzed the distributions of the lowest unoccupied molecular orbitals (LUMO) of the radical cations derived from benzimidazoles (I-III), benzoxazoles (IV, V), benzothiazoles (VI, VII), and 2-benzoxazolone (VIII) that bear multiple Me groups. As shown in Fig. 6b, the LUMOs are delocalized throughout the carbon skeletons of the benzoheterocycles with the distributions on $\mathrm{C} 6$ atoms being higher than other carbon atoms attached with a Me group. Furthermore, the natural population analysis shows that the charges of C6 are also more positive than those of other atoms bearing a Me group, indicating deprotonation of the C6-Me groups is preferred ${ }^{41}$.

In summary, we have shown that electrooxidation of methyl benzoheterocycles occurs in a site-selective manner to afford a wide range of structurally diverse aromatic acetals. The siteselectivity is governed by the innate electronic properties of the benzo ring instead of BDEs of the $\mathrm{C}\left(\mathrm{sp}^{3}\right)-\mathrm{H}$ bonds. The benzylic oxidation takes place efficiently in a simple undivided cell and employs traceless electric current as the reagents without need for stoichiometric chemical oxidants. These features render the reactions scalable and attractive for industrial scale applications.

\section{Methods}

Representative procedure for the electrooxidation of methylarenes. A $10 \mathrm{~mL}$ three-necked round-bottomed flask was charged with $\mathbf{1}(0.20 \mathrm{mmol}, 1.0$ equiv) and $\mathrm{Et}_{4} \mathrm{NPF}_{6}(0.10 \mathrm{mmol}, 0.5$ equiv). The flask was then equipped with a condenser, a reticulated vitreous carbon (100 PPI, $1.2 \mathrm{~cm} \times 1.0 \mathrm{~cm} \times 0.8 \mathrm{~cm}$ ) anode and a platinum plate $(1.0 \mathrm{~cm} \times 1.0 \mathrm{~cm})$ cathode, and flushed with argon. $\mathrm{MeOH}(9.0 \mathrm{~mL})$ was then added. The electrolysis was carried out at $80^{\circ} \mathrm{C}$ (oil bath temperature) using a constant current of $10 \mathrm{~mA}$ until complete consumption of the substrate $\left(2.3 \mathrm{~h}, 4.3 \mathrm{~F} \mathrm{~mol}^{-1}\right)$. The reaction mixture was cooled to RT and concentrated under reduced pressure. The residue was chromatographed through silica gel eluting with ethyl acetate/hexanes containing 1\% triethylamine to give the desired product $\mathbf{2}$ in 
a<smiles></smiles>
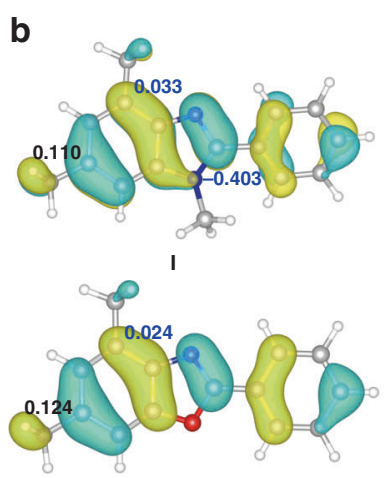

IV

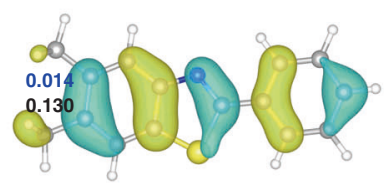

VII

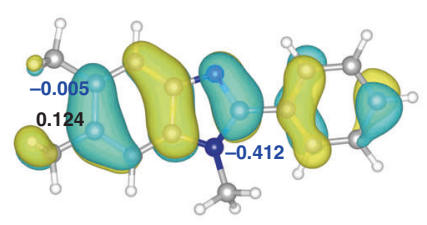

II

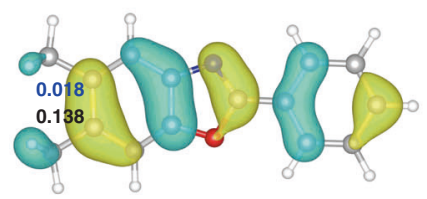

V

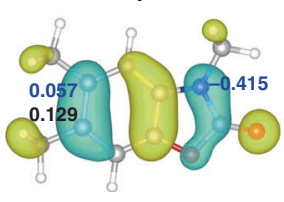

VIII

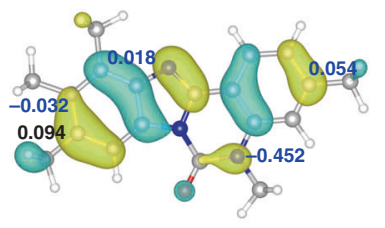

III

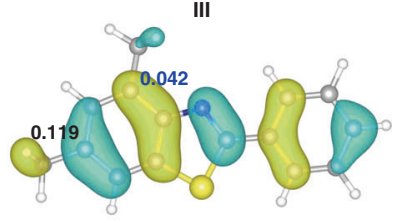

VI

Fig. 6 Investigation on the site-selectivity of the electrooxidation of methylarenes. a Radical bromination of $\mathbf{8 1}$ with NBS. $\mathbf{b}$ Computed LUMOs and NPA charges of radical cations derived from various methylated benzoheterocycles. N, C, O, S, and H atoms are colored in blue, gray, red, yellow and white, respectively. The LUMOs are visualized by light blue and yellow isosurfaces. The NPA charges of the atoms bearing a Me group are indicated by black (C6) and blue numbers. NBS N-bromosuccinimide, AIBN azobisisobutyronitrile.

$72 \%$ yield as a white solid. All new compounds were fully characterized (See the Supplementary methods).

\section{Data availability}

The X-ray crystallographic coordinates for structures reported in this study have been deposited at the Cambridge Crystallographic Data Centre (CCDC), under deposition number 1964756. These data can be obtained free of charge from The Cambridge Crystallographic Data Centre via www.ccdc.cam.ac.uk/data_request/cif. The data supporting the findings of this study are available within the article and its Supplementary Information files. Any further relevant data are available from the authors on request.

Received: 13 February 2020; Accepted: 7 May 2020;

Published online: 01 June 2020

\section{References}

1. Sterckx, H., Morel, B. \& Maes, B. U. W. Catalytic aerobic oxidation of $\mathrm{C}\left(\mathrm{sp}^{3}\right)$ -H bonds. Angew. Chem. Int. Ed. 58, 7946-7970 (2019).

2. Ishii, Y., Sakaguchi, S. \& Iwahama, T. Innovation of hydrocarbon oxidation with molecular oxygen and related reactions. Adv. Synth. Catal. 343, 393-427 (2001).

3. Yoshino, Y., Hayashi, Y., Iwahama, T., Sakaguchi, S. \& Ishii, Y. Catalytic oxidation of alkylbenzenes with molecular oxygen under normal pressure and temperature by $\mathrm{N}$-hydroxyphthalimide combined with $\mathrm{Co}(\mathrm{OAc})_{2}$. J. Org. Chem. 62, 6810-6813 (1997).

4. White, M. C. \& Zhao, J. Aliphatic C-H oxidations for late-stage functionalization. J. Am. Chem. Soc. 140, 13988-14009 (2018).

5. Nicolaou, K. C., Baran, P. S. \& Zhong, Y. L. Selective oxidation at carbon adjacent to aromatic systems with IBX. J. Am. Chem. Soc. 123, 3183-3185 (2001).

6. Fehr, C., Chaptal-Gradoz, N. \& Galindo, J. Synthesis of (-)-vulcanolide by enantioselective protonation. Chem. Eur. J. 8, 853-858 (2002).

7. Hosseinzadeh, R., Tajbakhsh, M. \& Vahedi, H. Selective oxidation of methylarenes with pyridinium chlorochromate. Synlett 2005, 2769-2770 (2005).
8. Sarma, B. B., Efremenko, I. \& Neumann, R. Oxygenation of methylarenes to benzaldehyde derivatives by a polyoxometalate mediated electron transfer-oxygen transfer reaction in aqueous sulfuric acid. J. Am. Chem. Soc. 137, 5916-5922 (2015).

9. Gaster, E., Kozuch, S. \& Pappo, D. Selective aerobic oxidation of methylarenes to benzaldehydes catalyzed by N-hydroxyphthalimide and cobalt(II) acetate in hexafluoropropan-2-ol. Angew. Chem. Int. Ed. 56, 5912-5915 (2017).

10. $\mathrm{Hu}, \mathrm{P}$. et al. Bio-inspired iron-catalyzed oxidation of alkylarenes enables latestage oxidation of complex methylarenes to arylaldehydes. Nat. Commun. 10, 2425 (2019).

11. Yan, M., Kawamata, Y. \& Baran, P. S. Synthetic organic electrochemical methods since 2000: on the verge of a renaissance. Chem. Rev. 117, 13230-13319 (2017).

12. Waldvogel, S. R., Lips, S., Selt, M., Riehl, B. \& Kampf, C. J. Electrochemical arylation reaction. Chem. Rev. 118, 6706-6765 (2018).

13. Yoshida, J.-i, Shimizu, A. \& Hayashi, R. Electrogenerated cationic reactive intermediates: the pool method and further advances. Chem. Rev. 118 , 4702-4730 (2018).

14. Sauermann, N., Meyer, T. H., Qiu, Y. \& Ackermann, L. Electrocatalytic C-H activation. ACS Catal. 8, 7086-7103 (2018).

15. Yang, Q. L., Fang, P. \& Mei, T. S. Recent advances in organic electrochemical C-H functionalization. Chin. J. Chem. 36, 338-352 (2018).

16. Kärkäs, M. D. Electrochemical strategies for C-H functionalization and C-N bond formation. Chem. Soc. Rev. 47, 5786-5865 (2018).

17. Feng, R., Smith, J. A. \& Moeller, K. D. Anodic cyclization reactions and the mechanistic strategies that enable optimization. Acc. Chem. Res. 50, 2346-2352 (2017)

18. Ye, Z. \& Zhang, F. Recent advances in constructing nitrogen-containing heterocycles via electrochemical dehydrogenation. Chin. J. Chem. 37, 513-528 (2019).

19. Francke, R. \& Little, R. D. Redox catalysis in organic electrosynthesis: basic principles and recent developments. Chem. Soc. Rev. 43, 2492-2521 (2014).

20. Yuan, Y. \& Lei, A. Electrochemical oxidative cross-coupling with hydrogen evolution reactions. Acc. Chem. Res. 52, 3309-3324 (2019).

21. Jiang, Y., Xu, K. \& Zeng, C. Use of electrochemistry in the synthesis of heterocyclic structures. Chem. Rev. 118, 4485-4540 (2018).

22. Nutting, J. E., Rafiee, M. \& Stahl, S. S. Tetramethylpiperidine N-oxyl (TEMPO), phthalimide N-oxyl (PINO), and related N-oxyl species: electrochemical properties and their use in electrocatalytic reactions. Chem. Rev. 118, 4834-4885 (2018). 
23. Xiong, P. \& Xu, H. C. Chemistry with electrochemically generated N-centered radicals. Acc. Chem. Res. 52, 3339-3350 (2019).

24. Sauer, G. S. \& Lin, S. An electrocatalytic approach to the radical difunctionalization of alkenes. ACS Catal. 8, 5175-5187 (2018).

25. Das, A., Nutting, J. E. \& Stahl, S. S. Electrochemical C-H oxygenation and alcohol dehydrogenation involving $\mathrm{Fe}$-oxo species using water as the oxygen source. Chem. Sci. 10, 7542-7548 (2019).

26. Horn, E. J. et al. Scalable and sustainable electrochemical allylic C-H oxidation. Nature 533, 77-81 (2016).

27. Cardoso, D. S. P., Sljukic, B., Santos, D. M. F. \& Sequeira, C. A. C. Organic electrosynthesis: from laboratorial practice to industrial applications. Org. Process Res. Dev. 21, 1213-1226 (2017).

28. Wendt, H. \& Bitterlich, S. Anodic synthesis of benzaldehydes-i. voltammetry of the anodic-oxidation of toluenes in nonaqueous solutions. Electrochim. Acta 37, 1951-1958 (1992).

29. Zhu, Y. H. et al. A promising electro-oxidation of methyl-substituted aromatic compounds to aldehydes in aqueous imidazole ionic liquid solutions. J. Electroanal. Chem. 751, 105-110 (2015).

30. Lumb, J. P. Stopping aerobic oxidation in its tracks: chemoselective synthesis of benzaldehydes from methylarenes. Angew. Chem. Int. Ed. 56, 9276-9277 (2017).

31. Cai, C.-Y., Shu, X.-M. \& Xu, H.-C. Practical and stereoselective electrocatalytic 1,2-diamination of alkenes. Nat. Commun. 10, 4953 (2019).

32. Cai, C.-Y. \& Xu, H.-C. Dehydrogenative reagent-free annulation of alkenes with diols for the synthesis of saturated O-heterocycles. Nat. Commun. 9, 3551 (2018).

33. Zhao, H.-B. et al. Amidinyl radical formation through anodic $\mathrm{N}-\mathrm{H}$ bond cleavage and its application in aromatic $\mathrm{C}-\mathrm{H}$ bond functionalization. Angew. Chem. Int. Ed. 56, 587-590 (2017).

34. Xu, F., Long, H., Song, J. \& Xu, H.-C. De novo synthesis of highly functionalized benzimidazolones and benzoxazolones through an electrochemical dehydrogenative cyclization cascade. Angew. Chem. Int. Ed. 58, 9017-9021 (2019).

35. Hou, Z.-W., Yan, H., Song, J.-S. \& Xu, H.-C. Electrochemical synthesis of (Aza)indolines via dehydrogenative [3+2] annulation: application to total synthesis of ( \pm )-hinckdentine A. Chin. J. Chem. 36, 909-915 (2018).

36. Wu, Z.-J., Li, S.-R., Long, H. \& Xu, H.-C. Electrochemical dehydrogenative cyclization of 1,3-dicarbonyl compounds. Chem. Commun. 54, 4601-4604 (2018).

37. Qian, X.-Y., Li, S.-Q., Song, J. \& Xu, H.-C. TEMPO-catalyzed electrochemical $\mathrm{C}-\mathrm{H}$ thiolation: synthesis of benzothiazoles and thiazolopyridines from thioamides. ACS Catal., 2730-2734 (2017).

38. Baciocchi, E., Bietti, M. \& Lanzalunga, O. Mechanistic aspects of $\beta$-bondcleavage reactions of aromatic radical cations. Acc. Chem. Res. 33, 243-251 (2000).

39. Brasche, G. \& Buchwald, S. L. C-H functionalization/C-N bond formation: copper-catalyzed synthesis of benzimidazoles from amidines. Angew. Chem. Int. Ed. 47, 1932-1934 (2008).

40. Ries, U. J. et al. 6-Substituted benzimidazoles as new nonpeptide angiotensin II receptor antagonists: synthesis, biological activity, and structure-activity relationships. J. Med. Chem. 36, 4040-4051 (1993).
41. Margrey, K. A., McManus, J. B., Bonazzi, S., Zecri, F. \& Nicewicz, D. A Predictive model for site-selective aryl and heteroaryl C-H functionalization via organic photoredox catalysis. J. Am. Chem. Soc. 139, 11288-11299 (2017).

\section{Acknowledgements}

The authors acknowledge the financial support of this research from MOST (2016YFA0204100), NSFC (No. 21672178, 21971213), and Fundamental Research Funds for the Central Universities.

\section{Author contributions}

P.Xiong and H.B.Z. contributed equally to this work. P.Xiong, H.B.Z., L.H.J., H.L., P.Xu, Z.J.L., and Z.J.W. performed the experiments and analyzed the data, X.T.F. and J.C. conducted the theoretical studies. H.C.X. designed and directed the project and wrote the manuscript.

\section{Competing interests}

The authors declare no competing interests.

\section{Additional information}

Supplementary information is available for this paper at https://doi.org/10.1038/s41467020-16519-8.

Correspondence and requests for materials should be addressed to J.C. or H.-C.X.

Peer review information Nature Communications thanks David Cardoso and the other, anonymous, reviewer(s) for their contribution to the peer review of this work. Peer reviewer reports are available.

Reprints and permission information is available at http://www.nature.com/reprints

Publisher's note Springer Nature remains neutral with regard to jurisdictional claims in published maps and institutional affiliations.

pen Access This article is licensed under a Creative Commons Attribution 4.0 International License, which permits use, sharing, adaptation, distribution and reproduction in any medium or format, as long as you give appropriate credit to the original author(s) and the source, provide a link to the Creative Commons license, and indicate if changes were made. The images or other third party material in this article are included in the article's Creative Commons license, unless indicated otherwise in a credit line to the material. If material is not included in the article's Creative Commons license and your intended use is not permitted by statutory regulation or exceeds the permitted use, you will need to obtain permission directly from the copyright holder. To view a copy of this license, visit http://creativecommons.org/ licenses/by/4.0/.

(c) The Author(s) 2020 